\title{
Five hundred years of printing
}

\section{Steinberg, S.H.}

New edition, revised by John Trevitt

London: British Library

1996

ISBN 0-7123-041402

Hard cover, illus., 262p.

Steinberg se boek is as 'n Penquin-uitgawe die eerste keer in 1955 gepubliseer en hy het self die tweede uitgawe in 1961 hersien. Die boek is ook in Duits gepubliseer en van die illustrasies in die Duitse uitgawe is in die 1961 Engelse uitgawe opgeneem. In 1974 het 'n derde hersiene uitgawe verskyn onder redaksie van James Moran. Die hersiene uitgawe wat hier bespreek word, is onderneem deur John Trevitt wat probeer het om die boek op datum te bring met moderne tendense op die gebied van die drukkuns. 
Die boek bly na al die jare steeds 'n standaardwerk oor die geskiedenis, verspreiding, tegnologiese vooruitgang en invloed wat die uitvinding van die boekdrukkuns op die wêreld gehad het. Eers in 1976 is Lucien Febvre en HenriJean Martin se boek, The coming of the book, in Engels vertaal. In die tagtigerjare het Elizabeth Eisenstein belangrike bydraes op dié gebied gelewer.

Trevitt het die basiese hoofstukverdeling van Steinberg behou. Hy het slegs die laaste hoofstuk in drie aparte hoofstukke verdeel. Die negentiende eeu, 1800-1900, word nou apart bespreek. Twee hoofstukke word aan die twintigste eeu gewy, van 1900-1955, waarna die na-oorlogse wêreld tot ongeveer 1995/6 volg.

In hierdie laaste twee hoofstukke gee hy aandag aan aspekte soos setwerk, drukwerk, sensuur, die boekhandel, bindwerk, ontwerp, CD-ROM en die Internet. Hy bespiegel oor die invloed van tegnologiese uitvindings op drukwerk. Naslaanwerke en wetenskaplike vaktydskrifte is dalk die kwesbaarste om deur elektroniese weergawes op die Internet vervang te word. In die lig van dié elektroniese ontwikkelings sal almal wat by boekproduksie betrokke is hul posisies moet heroorweeg. Hy betwyfel in 'n mate die wenslikheid daarvan dat alles op die Internet gepubliseer kan word.

'For over five hundred years printers and publishers have published what they have deemed worth publishing, and many thousand manuscripts have failed to achieve immortilization in print. While inevitably the world has been poorer for the loss of some of them, it is not unreasonable to believe in the value of this process of enlightened selection and rejection. From now on, "everything" on the Internet will include whatever any author chooses to publish on it' (p.249).

In sy gevolgtrekking wys Trevitt daarop dat die drukkuns, radio, televisie en die filmbedryf langs mekaar kan bestaan. Ondanks al dié tegnologiese deurbrake het dit nie gelei tot ' $n$ vermindering in boeklesers nie. Elkeen van die media het ' $n$ nismark gevind waar hulle mense se verskillende soorte inligtingbehoeftes bevredig. Dié siening kan onderskryf word soos wat deur ander navorsing op dié gebied reeds bewys is.

Die drukker het wel sy monopolie op die verspreiding van inligting verloor maar dit kan 'n positiewe ontwikkeling wees.

'However, as this open competition will certainly result in further improving the printer's craft it is all to the good. In the long run the general public, the last judge of the printer's endeavours, will benefit by it, and the printer will continue to hold the proud position of a man as Gutenberg's epitaph puts it "well deserving of all nations and languages"' (p.250).

Trevitt se hersienings is Steinberg se oorspronklike boek waardig en bring die boek op datum met die stand van die jongste ontwikkelings op die gebied van die drukkuns. Dit kan steeds as 'n onmisbare inligtingbron beskou word vir enigiemand wat 'n goeie oorsig oor die geskiedenis en invloed van die drukkuns oor byna seshonderd jaar wil kry. Die boek bevestig weer eens dat die uitvinding van die drukkuns met beweegbare metaalletters een van die mens se grootste prestasies was en steeds bly. Of ons nou bibliotekarisse of inligtingkundiges is, dié uitvinding bly vir ons van kardinale belang.

Die boek bevat ' $n$ baie goeie bibliografie vir verdere leeswerk. Dit is onder hoofde soos 'Historical and Biographical, Technical', ensovoorts, ingedeel. Die bibliografie bevat standaardwerke asook nuwe werke op dié onderskeie terreine.

Verder is die boek geillustreer met pragtige voorbeelde van uitstaande drukwerk. Dié voorbeelde kom feitlik almal uit boeke in die British Library en by elke voorbeeld word hulle standnommer in dié biblioteek gegee. Alhoewel die voorbeelde net in wit en swart is, was dit goeie keuses en verhoog dit die waarde van die boek vir die gebruiker. Die boek het ook 'n puik indeks.

Ek kan die boek aanbeveel vir aankoop deur biblioteke wat gebruikers het wat die geskiedenis van menslike kommunikasie bestudeer. Kommunikasiekundiges, bibliotekarisse, inligtingkundiges en kultuurhistorici sal dit 'n nuttige naslaanbron vind.

\section{J.C. THERON}

Departement Inligtingkunde, Universiteit van Suid-Afrika, Pretoria.

\section{Verwysings}

Eisenstein, E.L. 1983. The printing revolution in early modern Europe. Cambridge: University Press.

Febvre, L. \& Martin, H-J. 1984. The coming of the book: the impact of printing 1450-1800. London: Verso. 